\title{
Using Lead Concentrations and Stable Lead Isotope Ratios to Identify Contamination Events in Alluvial Soils
}

\author{
Diane Saint-Laurent, ${ }^{1}$ Julien St-Laurent, ${ }^{2}$ Marlies Hähni, ${ }^{3}$ Bassam Ghaleb, ${ }^{4}$ \\ and Camille Chapados ${ }^{3}$ \\ ${ }^{1}$ Géographie et Laboratoire de recherche en géomorphologie fluviale et sols, Université du Québec à Trois-Rivières, 3351, \\ boul. des Forges, C.P. 500, Trois-Riviéres, QC, Canada G9A 5H7 \\ ${ }^{2}$ Environnement et Développement durable, Ville de Trois-Rivières, C.P. 368, Trois-Rivières, QC, Canada G9A 5H3 \\ ${ }^{3}$ Département de Chimie et Biologie, Sciences de l'Environnement, Université du Québec à Trois-Rivières, 3351, \\ boul. des Forges, C.P. 500, Trois-Rivières, QC, Canada G9A 5H7 \\ ${ }^{4}$ GEOTOP, Université du Québec à Montréal, 210 Ave. Président-Kennedy, PK-7150, Montréal, QC, Canada H2X $3 Y 7$
}

Correspondence should be addressed to Diane Saint-Laurent, diane.saint-laurent@uqtr.ca

Received 23 March 2009; Revised 2 December 2009; Accepted 24 January 2010

Academic Editor: Artemi Cerda

Copyright (c) 2010 Diane Saint-Laurent et al. This is an open access article distributed under the Creative Commons Attribution License, which permits unrestricted use, distribution, and reproduction in any medium, provided the original work is properly cited.

Soils contaminated with hydrocarbons $\left(\mathrm{C}_{10}-\mathrm{C}_{50}\right)$, polycyclic aromatic hydrocarbons (PAHs), and other contaminants (e.g., As, $\mathrm{Cd}, \mathrm{Cu}, \mathrm{Pb}$ ) were recently discovered on the banks of the Saint-François and Massawippi rivers. Alluvial soils are contaminated over a distance of 100 kilometers, and the level of the contaminated-hydrocarbon layer in the soil profiles is among the highest at the Windsor and Richmond sites. Concentrations of lead and stable lead isotope ratios $\left({ }^{204} \mathrm{~Pb} /{ }^{206} \mathrm{~Pb},{ }^{207} \mathrm{~Pb} /{ }^{206} \mathrm{~Pb},{ }^{208} \mathrm{~Pb} /{ }^{206} \mathrm{~Pb}\right) \mathrm{are}$ also used to identify contamination events. The maximum and minimum values detected in soil profiles for arsenic, cadmium, and lead vary from 3.01 to $37.88 \mathrm{mg} \mathrm{kg}^{-1}$ (As), 0.11 to $0.81 \mathrm{mg} \mathrm{kg}^{-1}$ (Cd) 12.32 to $149.13 \mathrm{mg} \mathrm{kg}^{-1}$ (Pb), respectively, while the ${ }^{207} \mathrm{~Pb} /{ }^{206} \mathrm{~Pb}$ isotopic ratio values are between 0.8545 and 0.8724 for all the profiles. The highest values of trace elements $(\mathrm{As}, \mathrm{Pb}$ and $\mathrm{Zn})$ were detected in the hydrocarbon layer $\left(\mathrm{C}_{10}-\mathrm{C}_{50}\right)$, most often located at the bottom of the profiles $(160,200$, and $220 \mathrm{~cm}$ in depth). The various peaks recorded in the soils and the position of the profiles suggest that various contaminants were transported by the river on several occasions and infiltrated the soil matrix or deposited on floodplains during successive floods. Atmospheric particles which entered the river or deposited on riverbanks must also be considered as another source of pollution recorded in soils.

\section{Introduction}

In the recent years, a growing number of environmental science studies on soil and sediment contamination were characterized by the use of lead stable isotopes to determine the source and origin of this element (geogenic or anthropic) and to evaluate its persistence in the environment [1-3]. Mining and industrial activity have introduced various forms of lead pollutants into the environment and the intensive use of fossil fuels has also resulted in lead and several other heavy metals affecting the environment to varying degrees $[4,5]$. In the past two decades, research has examined lead isotope signatures to trace emission sources and assessed spatial and temporal changes of recent lead pollution originating from lead smelters and manufacturing plants and from the use of alkyllead in petroleum products, particularly before 1990 $[6,7]$. The atmosphere is recognized as major means of transport [8], but fluvial transport also constitutes a vector of pollution [9-11]. Studies also examined lead contamination in soils, sediments and groundwater aquifers along with other metals that are generally geochemically associated (e.g., $\mathrm{Cd}$, As and $\mathrm{Zn})[12,13]$. Results showed that lead isotopes serve as indicators of environmental contamination events affecting a large spectrum of environmental media.

Other researchers have drawn on a combination of lead and lead isotope ratios $\left({ }^{207} \mathrm{~Pb} /{ }^{206} \mathrm{~Pb},{ }^{208} \mathrm{~Pb} /{ }^{206} \mathrm{~Pb}\right)$ as geochemical tracers to recognize the succession of atmospheric and pedogeochemical changes related to industrial activities 
in the mining area $[11,14]$. Lead is widely considered immobile and persistent in soils, though its mobility in soil can increase with a high concentration of organic matter complex or chelate, which can play a key role in the movement of iron and other elements in the profile $[14,15]$. Stable lead isotope ratios can be used as a complementary tool in dating contamination events and for the evaluation of sedimentation rates, including the use of lead-210 $[3,16,17]$. Lead has four stable isotopes $\left({ }^{204} \mathrm{~Pb},{ }^{206} \mathrm{~Pb},{ }^{207} \mathrm{~Pb}\right.$ and ${ }^{208} \mathrm{~Pb}$ ) while the radioactive decay of ${ }^{238} \mathrm{U},{ }^{235} \mathrm{U}$ and ${ }^{232} \mathrm{Th}$ produces radiogenic lead isotopes $(206,207$, and $208 \mathrm{~Pb})$ [8, 16]. Although the various sources of lead have specific isotopic signatures, stable lead isotopes have been used generally to distinguish between lead originating from natural or anthropogenic sources $[2,18]$. Lead isotope analysis has proved to be an effective technique for identifying the origin of lead in different terrestrial, marine and aquatic ecosystems $[1,12,13]$. Also, the isotopic composition of lead is not affected to any measurable extent by physical or chemical processes [6].

This study focuses on a case of contamination along the riverbanks of the Saint-François and Massawippi rivers (Québec, Canada) that was never officially reported by the government. This recent discovery led to the identification of soils contaminated by $\mathrm{C}_{10}-\mathrm{C}_{50}$ hydrocarbons and other pollutants (e.g., heavy metals). The contamination extends more than over more than 100 kilometers of riverbank between the municipalities of Eustis and Drummondville (Southern Québec). The objective of this study is to attempt to identify the contamination events through the use of pedologic and radiogenic methods, including an analysis of heavy metals (e.g., $\mathrm{Cd}, \mathrm{Cu}, \mathrm{Ni}, \mathrm{Zn}$ ) and lead concentrations, stable lead isotope ratios $\left({ }^{204} \mathrm{~Pb} /{ }^{206} \mathrm{~Pb},{ }^{207} \mathrm{~Pb} /{ }^{206} \mathrm{~Pb}\right.$, $\left.{ }^{208} \mathrm{~Pb} /{ }^{206} \mathrm{~Pb}\right)$ and sedimentation rates $\left({ }^{210} \mathrm{~Pb}\right)$ in alluvial soils. This study focuses on the lead concentration and the pattern of lead isotopic composition found in floodplain soils. The use of lead in petroleum products (e.g., gasoline, heating oil) before 1990 and its prohibition in Canada after this date (the phasing out of leaded gasoline in Canada started in the 1980s and leaded gasoline was finally prohibited in 1990 $[6,19]$.) provides a relatively good indicator of hydrocarbon contamination (presence of lead) in the overbank sediments, and helps estimate the date of the contamination events by using radiogenic data (lead isotopic signatures and lead-210).

\section{Materials and Methods}

2.1. Sites Location. The sites under study are located along the Saint-François and Massawippi rivers (Figure 1) and form part of the Saint-François watershed basin, which covers a surface area of $10,230 \mathrm{~km}^{2}$. Ranging from an altitude of 304 to $762 \mathrm{~m}$ above sea level, it reaches its peak on the American side of the Appalachian Mountains (VT). In the upstream part of the basin, the relief is characterized by mountains, hills and valleys dominated by wooded areas and agricultural lands, while the downstream part of the basin is a flat landscape of farmland, small towns, and the city of Sherbrooke. The riverbanks are characterized by different distinct geomorphological sections comprised of glacial, glaciofluvial outwash or glaciolacustrine materials and fluvial deposits. The middle section of the Saint-François and Massawippi rivers (sampling sites) is characterized by low floodplains (less than $3 \mathrm{~m}$ high) covered by overbank sediments composed mainly of silty and fine sandy loam materials and immature soils like regosolic and cumulic regosol soils [20]. Subject to periodic flooding. These rivers may experience more than one flood per year [17]. They go through former industrial and mining areas and agriculture lands that are major factors in the degradation of water quality. Traces of contamination (e.g., hydrocarbons, PAHs and heavy metals) have in fact been observed in alluvial soils along the riverbanks [17]. In addition to the many industrial activities, mining has long been one of the main sources of pollutant discharge in area watercourses, primarily the Massawippi River. Several thousand tons of copper, nickel and tungsten were produced at the Eustis-Capelton mines. A study showed that these mines were responsible for copper concentration in the Saint-François and Massawippi rivers $[21,22]$.

\subsection{Sampling and Laboratory Analysis. Field investigations} were undertaken on overbank sediments found at four sites (Figure 1). These sampling sites are located along riverbanks on recent alluvial soils (less than one thousand years). For each site, a trench was dug along the riverbank in order to reach the contaminated layers (the hydrocarbon layer), which in some cases were found at more than one metre in depth. In all, 90 soil samples were taken from the five profiles (MAS-13, STE-1, STE-1-2, STO-6 and RIC-9). A detailed morphological description of the profiles was used to characterize the texture, color horizon (Munsell chart) and depth of the hydrocarbon layer. In addition, soil horizons were identified in the field using the criteria of the Canadian System of Soil Classification [23, 24]. Soil samples were collected in the profile in 20 -cm-deep sections until the contaminated hydrocarbon layer was reached. Soil samples were analyzed in the laboratory to characterize the textural composition, $\mathrm{pH}$ and total organic carbon (TOC). For the grain size analysis, the dry sandy fraction was obtained by sieving, while the finer fractions were obtained using a hydrometer (Boyoucos method). The methods used for the chemical analyses consisted of determining the $\mathrm{pH}$ in using a $1: 2$ soil-solution ratio $\left(\mathrm{CaCl}_{2}: 0.01 \mathrm{M}\right)$ and the TOC content methods $[25,26]$.

The hydrocarbon sample analysis was done using gas chromatography coupled with a flame ionization detector (GC-FID). The detection limit for the $\mathrm{C}_{10}$ to $\mathrm{C}_{50}$ hydrocarbons was $60 \mathrm{mg} \mathrm{kg}^{-1}$ of dry matter. For metal concentrations $(\mathrm{Pb}, \mathrm{As}, \mathrm{Cd}, \mathrm{Cu}$ and $\mathrm{Zn})$ and lead isotopic analysis, soil samples were mixed in a receptacle to ensure homogeneity, stored in sterile containes, and refrigerated at the site. Sampling methods used are in accordance with standards established by the Ministère de l'Environnement du Québec $[27,28]$ and the Institut national de la recherche scientifique Centre - Eau Terre Environnement (INRS-ÉTÉ), Centre géoscientifique de Québec (CGQ), and BIOLAB laboratory 


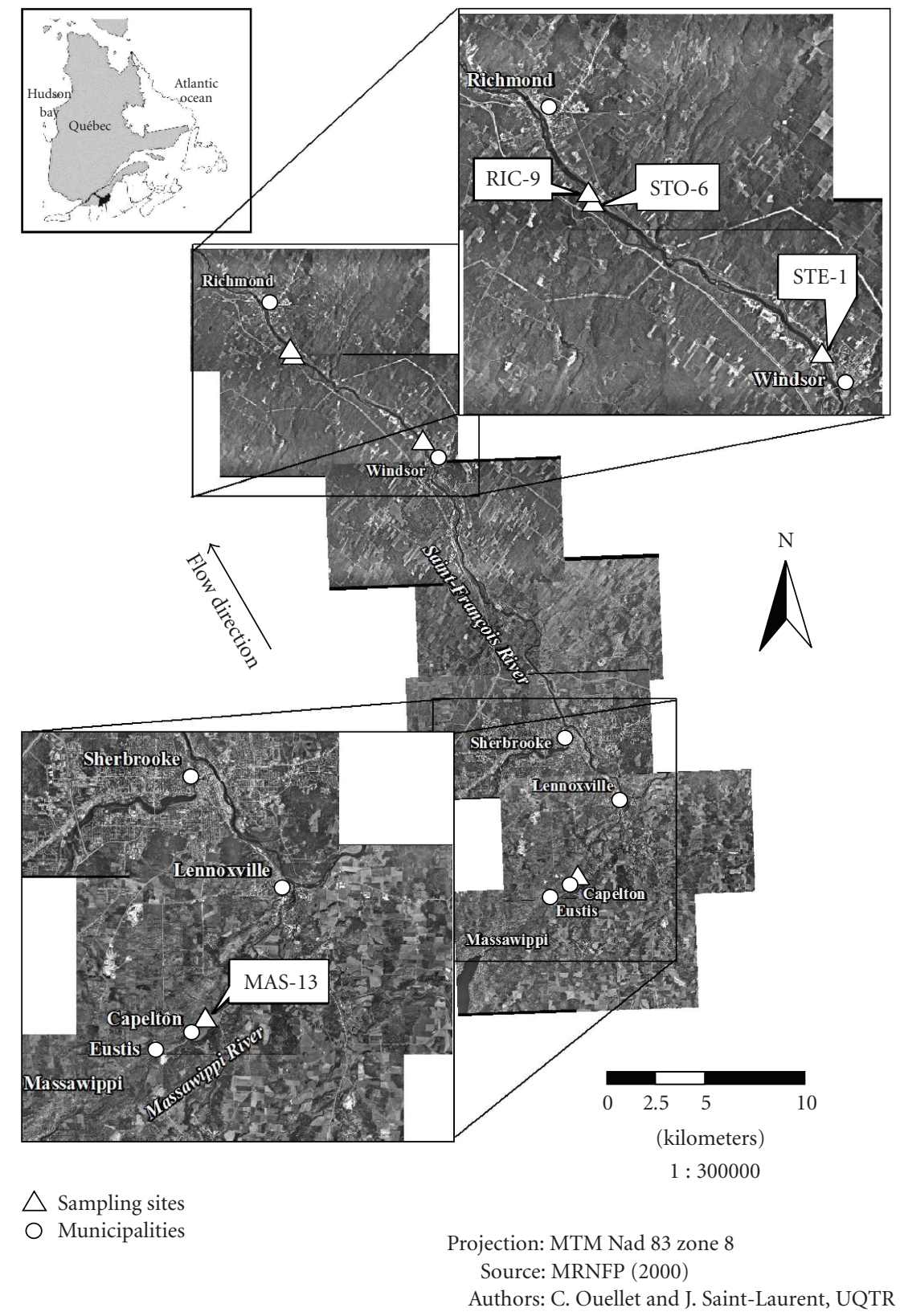

FIGURE 1: Study area and location of the sampling sites at Richmond (RIC-9, STO-6), Windsor (STE-1) and Massawippi (MAS-13) in southern Québec.

protocols. The samples were used to analyze heavy metals and lead concentrations as well as isotope ratios $\left({ }^{204} \mathrm{~Pb} / 206 \mathrm{~Pb}\right.$, ${ }^{207} \mathrm{~Pb} /{ }^{206} \mathrm{~Pb},{ }^{208} \mathrm{~Pb} /{ }^{206} \mathrm{~Pb}$ ). Metal concentration levels were determined using an extraction procedure adopted by the Ministère de l'Environnement [28]. At the INRS geochemistry laboratory (INRS-ETE/Delta Lab), the soil samples were dissolved using $\mathrm{HNO}_{3}$, and the resulting liquid residue analyzed by inductively coupled plasma-mass spectrometers (ICP-MS) to obtain trace metal concentrations and isotopic compositions. Blank samples were prepared for every batch of 10 or 12 samples. For $\mathrm{Pb}$ concentration analysis, the complete procedures, including the duplicate analyses required to validate the laboratory tests, are available in government documents [28]. The quality control and acceptability criteria (QA/QC) had to conform to document DR-12-SCA-01 from the Ministère de l'Environnement [28] and applied as follows: (i) the curve determination coefficient should be at least 0.995; and (ii) the duplicate analytical method must be under the methodological quantification limit (MQL). The randomly tested check standards should not exceed $20 \%$ of the target value, except for the level 1 standard, which is used to ensure adequate sensitivity. 
TABLE 1: Description of sampling sites and some characteristics of soil profiles.

\begin{tabular}{|c|c|c|c|c|c|}
\hline Location/Site/soil profile & $\begin{array}{c}\text { Massawippi } \\
\text { MAS-13/MAS-13 }\end{array}$ & $\begin{array}{c}\text { Windsor } \\
\text { STE-1/STE-1 }\end{array}$ & $\begin{array}{c}\text { Windsor } \\
\text { STE-1/STE-1-2 }\end{array}$ & $\begin{array}{l}\text { Richmond } \\
\text { STO-6/STO-6 }\end{array}$ & $\begin{array}{l}\text { Richmond } \\
\text { RIC-9/RIC-9 }\end{array}$ \\
\hline UTM (NAD-83) & 2732945022783 & 7329285051683 & 7329295051682 & 7243765057125 & 7241755057482 \\
\hline Soil type & $\begin{array}{l}\text { Cumulic Regosol } \\
\text { (CU.R) }\end{array}$ & $\begin{array}{l}\text { Cumulic Regosol } \\
\text { (CU.R) }\end{array}$ & $\begin{array}{l}\text { Cumulic Regosol } \\
\text { (CU.R) }\end{array}$ & $\begin{array}{l}\text { Cumulic Regosol } \\
\text { (CU.R) }\end{array}$ & Regosol (CU.) \\
\hline Textural class (see $[24]$ ) & Sandy loam & Loam & Loam/sandy loam & Sandy loam & Loamy sand \\
\hline Soil pH $0.01 \mathrm{M} \mathrm{CaCl}_{2}$ & $3.45-6.09$ & $5.98-7.09$ & $5.32-5.92$ & $4.28-5.03$ & $4.71-5.38$ \\
\hline C. org. (\%) & $0.12-1.02$ & $0.39-0.68$ & $0.64-0.91$ & $0.36-1.48$ & $1.12-1.44$ \\
\hline $\begin{array}{l}\text { Depth of hydrocarbon } \\
\text { layer }(\mathrm{cm})\end{array}$ & 220 & 180 & 32 & 60 & $\begin{array}{c}\text { No trace of } \\
\text { hydrocarbons }\end{array}$ \\
\hline $\begin{array}{l}\text { Hydrocarbon } \mathrm{C}_{10}-\mathrm{C}_{50} \\
\text { concentrations }\left(\mathrm{mg} \mathrm{kg}^{-1}\right)\end{array}$ & $<60$ & 660 & 340 & $<80$ & 一 \\
\hline $\begin{array}{l}\text { Hydrocarbon layer color } \\
\text { (Munsell Chart) }\end{array}$ & $10 Y R 4.5 / 2$ & 10 YR $2.5 / 2$ & 10YR $2.5 / 2$ & 10 YR $5 / 3$ & $10 Y R 3 / 3$ \\
\hline
\end{tabular}

2.3. Age Dating and Sedimentation Rates with Pb. The isotopic ${ }^{210} \mathrm{~Pb}$ dating method was used for soil profile at STE 1 (Windsor site) to determine sedimentation rates based on radionuclide activity in sediments. For this, the lead 210 CRS model (Constant Rate of Supply) was used to a close correlation between depth and time $[3,4,29]$ given that excess ${ }^{210} \mathrm{~Pb}$ activity diminishes theoretically in an exponential manner, thus determining the sedimentation rate [29]. There are two types of ${ }^{210} \mathrm{~Pb}$ : the first originating directly from the atmosphere (supported or unsupported excess ${ }^{210} \mathrm{~Pb}$ ) and the second produced in situ as a result of radium disintegration $\left({ }^{226} \mathrm{Ra}\right)$, originating from 238 Uranium in the analyzed sediments (supported lead). It is assumed that the flow of the lead originating from the atmosphere is constant from year to year, and it becomes possible to estimate the sedimentation rates over relatively long periods [29]. The work by Nriagu [30] in fact shows greater use of lead after 1800, which constitutes an additional indicator in the interpretation of anthropogenic sources of pollution.

The method used for ${ }^{210} \mathrm{~Pb}$ age dating is alpha spectroscopy, a technique that offers greater flexibility compared to beta spectroscopy and more precision compared to gamma ray spectroscopy. The alpha spectroscopy method is used by the GEOTOP-UQAM-McGILL laboratory where the analyses were performed. A more complete description of the methods was provided elsewhere [17].

\section{Results and Discussion}

3.1. Alluvial Soils and Hydrocarbon-Contaminated Layers. The alluvial soils analyzed have been classified in the Cumulic Regosol (CU.R) subgroup of the Canadian System of Soil Classification [24]. The soils show little development and are characterized by the absence of Ah horizons and accumulation horizons (B), as well as by little chemical alteration. The soils that were analyzed generally show $\mathrm{pH}$ values ranging from 3.45 to 7.09 with an average value of 4.63 and TOC rates ranging from 0.12 to $1.48 \%$
(Tables 1 and 2). The $\mathrm{pH}$ values in the soil (MAS-13) of the mining area (Eustis-Capelton) were more acidic at the bottom of the profile $(120 \mathrm{~cm}$ and more), probably due to the presence of acidified toxic waste [21] found at the base of the soil profile, which come from the former Eustis mining site [22] located a few kilometres upstream. Most of the alluvial soils examined are made up of fine material, mainly fine sandy loam, fine loamy sand or sandy loam (Tables 1 and 2), which is a common feature of flood or fluvial deposits in these rivers $[17,20]$. It could be said that this textural uniformity (basically fine material) is the dominant characteristic of the soils that form the floodplains of the rivers under study. It should be noted that the fine-textured soils retain more contaminants than the coarse matrix [31, 32].

The field observations and the samples taken from the riverbanks reveal that the most highly contaminated soils extend from Eustis to Windsor (Figure 2). The banks of the Massawippi River contain contaminants that can be traced back to the former Eustis mine, while no contamination was observed in the soil materials upstream of the site. From Eustis to Richmond, however, both riverbanks are contaminated with hydrocarbons $\left(\mathrm{C}_{10}-\mathrm{C}_{50}\right)$ and heavy metals (see also [33]). Considering the thickness of the contaminated soil, the most problematic sites are those in the Massawippi area. The contaminated layers may extend over more than one metre in depth in the riverbank deposits and the coloration and odor are more pronounced. Based on these observations, the origin of the discharge would appear to be Eustis. The former mining site is still being used as a storage area for pulp and paper waste and served as a landfill for mining waste containing copper, lead and zinc [21]. The contaminated soil sample taken at the Eustis mine site (EUS) showed a relatively high $\mathrm{C}_{10}-\mathrm{C}_{50}$ hydrocarbon contamination rate, that is, $380 \mathrm{mg} \mathrm{kg}^{-1}$ of dry matter. At the Massawippi site (MAS-13), the rate is $<60 \mathrm{mg} \mathrm{kg}^{-1}$, and for the Windsor (STE-1, STE-1-2) and Richmond (STO-6) sites the values varied from 660 to $80 \mathrm{mg} / \mathrm{kg}$ (Table 1 ). The deepest contaminated hydrocarbon layers $\left(\mathrm{C}_{10}-\mathrm{C}_{50}\right)$ were found at the Massawippi (MAS-13 profile) and Windsor 
TABLE 2: Soil properties and lead concentrations in soil samples collected at contamined sites (MAS-13, STO-6) and uncontaminated site (RIC-9).

\begin{tabular}{|c|c|c|c|c|c|}
\hline Soil Profile & Depth $(\mathrm{cm})$ & $\mathrm{pH}$ & $\begin{array}{c}\text { Total organic } \\
\text { carbon }(\%)\end{array}$ & Textural class ${ }_{a}$ & $\mathrm{~Pb}\left(\mathrm{mg} \mathrm{kg}^{-1}\right)$ \\
\hline \multicolumn{6}{|l|}{ Contaminated sites } \\
\hline \multicolumn{6}{|l|}{ MAS-13 } \\
\hline & $0-20$ & 6.09 & 0.31 & FSL & 18.73 \\
\hline & $20-40$ & 5.50 & 0.30 & FSL & 18.38 \\
\hline & $40-60$ & 5.37 & 0.34 & FSL & 22.38 \\
\hline & $60-80$ & 5.59 & 0.54 & FSL & 17.79 \\
\hline & $80-100$ & 5.46 & 0.12 & FSL & 19.18 \\
\hline & $100-120$ & 5.24 & 0.42 & FSL & 21.84 \\
\hline & $120-140$ & 3.83 & 0.85 & FLS & 36.34 \\
\hline & $140-160$ & 3.63 & 0.95 & FLS & 49.65 \\
\hline & $160-180$ & 4.07 & 0.75 & FLS & 42.18 \\
\hline & $180-200$ & 3.45 & 0.72 & FLS & 121.80 \\
\hline & $200-220$ & 3.45 & 1.02 & SL & 149.13 \\
\hline & $220-240$ & 3.97 & 0.55 & MFS & 22.41 \\
\hline \multicolumn{6}{|l|}{ STO-6 } \\
\hline & $0-20$ & 5.03 & 1.48 & FSL & 25.25 \\
\hline & $20-40$ & 4.77 & 1.21 & FSL & 35.74 \\
\hline & $40-60$ & 4.43 & 0.63 & FSL & 37.29 \\
\hline & $60-80$ & 4.28 & 0.71 & FSL & 30.57 \\
\hline & $80-100$ & 4.56 & 0.36 & FSL & 12.32 \\
\hline \multicolumn{6}{|c|}{ Uncontaminated site (without hydrocarbons layer) } \\
\hline \multicolumn{6}{|l|}{ RIC-9 } \\
\hline & $0-20$ & 5.38 & 1.44 & FSL & 25.73 \\
\hline & $20-40$ & 5.26 & 1.25 & FSL & 34.38 \\
\hline & $40-60$ & 4.71 & 1.10 & FSL & 34.88 \\
\hline Maximum value & - & 6.09 & 1.48 & - & 149.13 \\
\hline Minimum value & - & 3.45 & 0.12 & - & 12.32 \\
\hline Average value & - & 4.70 & 0.75 & - & 38.80 \\
\hline
\end{tabular}

${ }^{a}$ : FSL: Fine sandy loam; FLS: Fine loamy sand; SL: Sandy loam; MFS: Medium fine sand (see [24]).

sites (STE-1 profile), with depths of $200-220 \mathrm{~cm}$ and 160 $180 \mathrm{~cm}$, respectively. In some other soil profiles found in the Massawippi and Saint-François rivers [33], the hydrocarbon layers can be found at the surface $(5-10 \mathrm{~cm})$ of the profiles and a depths from 60 to $90 \mathrm{~cm}$. This points to either a remobilization of contaminated layers during flooding or local and site-specific spills. Lastly, profile RIC-9, found more than 30 metres from the riverbank, does not show any trace of hydrocarbons, unlike the other profiles.

In reviewing the information recorded in the archives of the Société d'Histoire de Sherbrooke (e.g., regional newspapers), the pollution events seem to have occurred on two separate occasions in the Saint-François River, that is, October 25, 1955 and May 17, 1963, though no details on the events or their causes are provided. The 1963 newspaper article mentions the presence of large expanses of oil on the river in the Sherbrooke area (Figure 1). There were no newspaper articles on cases of river contamination (e.g., oil discharge) for the Massawippi River. However, it is probable that other contamination events (e.g., local contamination) occurred but were not all mentioned in the documents that were consulted. However, the presence of over more than $100 \mathrm{~km}$ of riverbank contaminated by hydrocarbons $\left(\mathrm{C}_{10}-\right.$ $\mathrm{C}_{50}$ ) points to one or more major spills in the river.

3.2. Heavy Metals Concentrations and Lead Isotope Ratios in Soil Profiles. The results obtained for lead and other metal concentrations of soil profiles for the selected sites (Richmond, Windsor and Massawippi) are presented in Figure 3, and Tables 2 and 3. The concentration levels of the metal elements analyzed must comply with the Environment Ministry's standards for contaminated sites [27, 28] developed for criteria A, B and C, that is, 6,30 and $50 \mathrm{mg} \mathrm{kg}^{-1}$ for arsenic (As), 1.5, 5 and $20 \mathrm{mg} \mathrm{kg}^{-1}$ for cadmium (Cd), 40,100 and $500 \mathrm{mg} \mathrm{kg}^{-1}$ for copper $(\mathrm{Cu}), 50,500$ and $1500 \mathrm{mg} \mathrm{kg}^{-1}$ for lead $(\mathrm{Pb})$ and 110,500 and $1500 \mathrm{mg} \mathrm{kg}^{-1}$ for zinc $(\mathrm{Zn})$, respectively. In general, $\mathrm{Pb}$ concentrations 


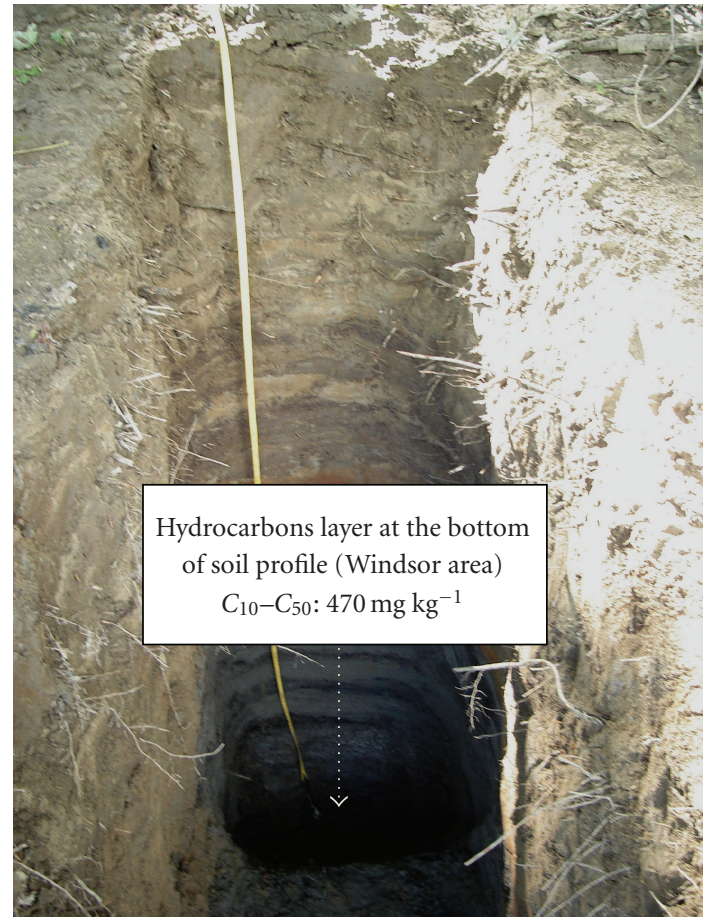

Figure 2: Soil profile with the hydrocarbon layer $\left(\mathrm{C}_{10}-\mathrm{C}_{50}\right)$ at a depth of 160-180 cm. The contaminated layer can be more than $30 \mathrm{~cm}$ thick in the riverbank in the Windsor area (left bank).

and other metal or metalloid elements (e.g., As, Cd) are relatively low, except for the MAS-13 profile, which exceeds the concentration of criterion A for arsenic $\left(37.9 \mathrm{mg} \mathrm{kg}^{-1}\right)$ and lead (121.8 and $\left.149.1 \mathrm{mg} \mathrm{kg}^{-1}\right)$. This profile shows distinctive peaks (160 and $220 \mathrm{~cm}$ depth) of contamination (Figure 3). The As and $\mathrm{Pb}$ concentrations are more elevated deeper in the profile than on the surface, which is usually the case in contaminated soils where the sources of lead and other elements are inputs by atmospheric pollutants $[10,16]$. As the highest concentrations are found at the bottom of the soil profile (more than one metre), it is likely that contamination (hydrocarbon layers) from pollutants was carried off by the river at low levels. In fact, virtually all the soil profiles observed in the Massawippi area contained hydrocarbon layers at the bottom of the profiles. Samples of the contaminated layers can only be taken when the Massawippi River is at low levels, that is, around 3.76 and $6.61 \mathrm{~m}^{3} / \mathrm{s}$, most often during September and early October [34].

Soil profile STE-1 at $180 \mathrm{~cm}$ containing lead showed concentration levels that slightly exceeded criterion A with a value of $50.82 \mathrm{mg} \mathrm{kg}^{-1}$ (Figure 3). This sample was taken directly from the contaminated hydrocarbon layer (160$180 \mathrm{~cm}$ depth). In the same profile (STE-1), with respect to other metal element concentration levels (e.g., $\mathrm{Cu}$ and $\mathrm{Zn}$ ), some samples had values that exceeded criterion A (Table 3), except for the upper horizons $(0-40 \mathrm{~cm})$. These results can serve as indicators of the contamination events (oil discharges most likely) that occurred probably at different times along the Saint-François River. For profile STO-6, the concentration of heavy metal and metalloid elements analyzed (e.g., As, $\mathrm{Cd}$, and $\mathrm{Pb}$ ) was higher in the subsurface horizons (40-60 cm depth), which suggests contaminants leaching to the lower layers or resulting from the infiltration of pollutants into the riverbanks by polluted waters. For the RIC-9 profile, the concentrations of $\mathrm{As}, \mathrm{Cd}$ and $\mathrm{Pb}$ are comparable with the values obtained for the STO-6 profile and show a similar pattern for $\mathrm{Cd}$ and $\mathrm{Pb}$ (Figure 3). Maximum concentrations of lead, for example, are reached at a depth of $40 \mathrm{~cm}\left(34.4 \mathrm{mg} \mathrm{kg}^{-1}\right)$, a similar value to that obtained for the STO- 6 profile $\left(35.7 \mathrm{mg} \mathrm{kg}^{-1}\right)$ at the same depth $(40 \mathrm{~cm})$. Note that profile RIC-9 is situated $31 \mathrm{~m}$ away from the riverbanks and no trace of soil contaminated with hydrocarbons was detected in the profile. It is possible, however, that other pollutants (such as $\mathrm{Cd}$ and $\mathrm{Pb}$ ) carried off by the river may have possibly reached this site (RIC-9) during major floods [35], or that these contaminants found in subsurface layers $(20-40 \mathrm{~cm})$ come from atmospheric fallout. It is known that the fine particulate matter of lead and of other pollutants can be transported over long distances $[2,3]$ and be redeposited on the soil surface. Over time, these pollutants penetrate the lower horizons through migration or leaching $[12,36]$; cadmium and zinc are usually more easily remobilized than lead, however [15]. Still, the concentrations of trace metals $(\mathrm{As}, \mathrm{Cd}, \mathrm{Pb})$ detected on the surface of the profiles (RIC-9 and STO-6) are rather low.

The values of all the profiles (Figure 3 ) show many peaks that indicate a concentration level of lead and other elements (As, Cd) found at depths of 40,60 , and $80 \mathrm{~cm}$ and two peaks with stronger concentration levels of $\mathrm{Cd}$ at depths of 100 and $180 \mathrm{~cm}$ in the STE- 1 profile, a relative high concentration of As at a depth of $80 \mathrm{~cm}$ in profile STO-6, and very high concentrations of $\mathrm{As}, \mathrm{Cd}$ and $\mathrm{Pb}$ at a depth of $220 \mathrm{~cm}$ in profile MAS-13. These peaks in the soil profiles suggest several separate contamination events that might be associated with various pollutant discharges into the river. The peaks found at the bottom of the soil profiles $(100,180$ or $220 \mathrm{~cm}$ ) can only really be associated with the transport of pollutants by the river due to their position in the profile, while the pollutants found at lower depths $(40 \mathrm{~cm})$ most likely also come from the transport of pollutants by the river [32], but contamination through atmospheric fallout (e.g., anthropogenic deposition in the soil surface) cannot be ruled out. These two likely sources (river and atmosphere) could partly account for the variability of the isotopic values found in the different profiles (Figure 4), though such variability could be attributable to the type of products discharged into the river or transported by it (e.g., mixing of lead with the hydrocarbon layer or lead from mine waste).

The values obtained for lead isotope ratios in the soil profiles ranged from 0.0548 to $0.562\left({ }^{204} \mathrm{~Pb} /{ }^{206} \mathrm{~Pb}\right), 0.851$ to $0.872\left({ }^{207} \mathrm{~Pb} /{ }^{206} \mathrm{~Pb}\right)$ and 2.081 to $2.111\left({ }^{208} \mathrm{~Pb} /{ }^{206} \mathrm{~Pb}\right)$. For each profile, the ${ }^{207} \mathrm{~Pb} /{ }^{206} \mathrm{~Pb}$ isotope ratios obtained varied between 0.851 and 0.867 (MAS-13), 0.855 and 0.872 (STE1), 0.852 and 0.868 (STO-6), and 0.860 and 0.865 (RIC9), respectively (Figure 4). The isotope ratios of ${ }^{208} \mathrm{~Pb} /{ }^{206} \mathrm{~Pb}$ obtained for the same soil profiles show a similar pattern that was observed for the ${ }^{207} \mathrm{~Pb} /{ }^{206} \mathrm{~Pb}$ ratios. For example, 

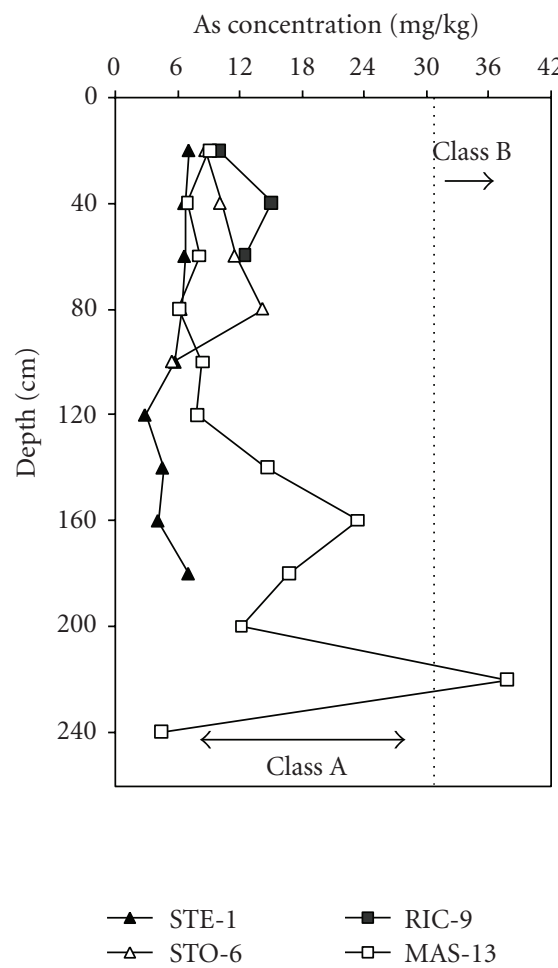

(a)

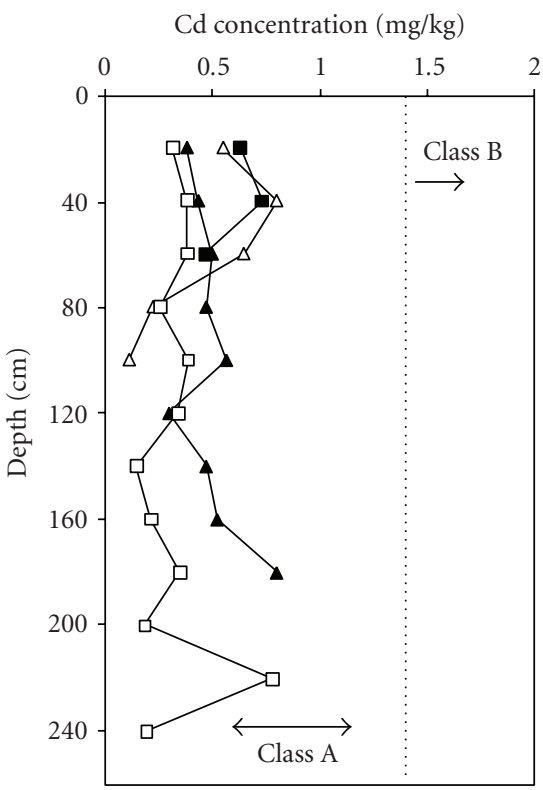

$\rightarrow$ STE- 1

$\rightarrow$ RIC-9

$\rightarrow$ MAS-13

(b)
$\mathrm{Pb}$ concentration $(\mathrm{mg} / \mathrm{kg})$

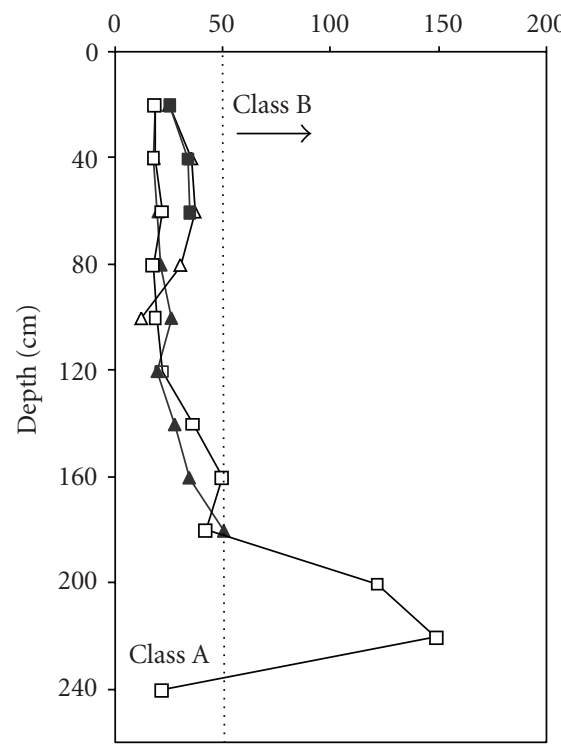

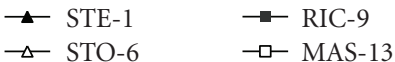

(c)

Figure 3: As, Cd and Pb concentrations in selected soil profiles (STE-1, STO-6, RIC-9 and MAS-13). The dotted line delimits classes A and $\mathrm{B}$ of soil contamination based on the MDDEP criterion [19].

TABLE 3: Lead and heavy metal concentrations and Pb isotopic compositions in soil profile at Windsor site (STE-1).

\begin{tabular}{|c|c|c|c|c|c|c|c|c|}
\hline Depth $(\mathrm{cm})$ & As mg kg-1 & $\mathrm{Cd} \mathrm{mg} \mathrm{kg}-1$ & $\mathrm{Cu} \mathrm{mg} \mathrm{kg}{ }^{-1}$ & $\mathrm{~Pb} \mathrm{mg} \mathrm{kg}{ }^{-1}$ & $\mathrm{Zn} \mathrm{mg} \mathrm{kg}{ }^{-1}$ & ${ }^{204} \mathrm{~Pb} /{ }^{206} \mathrm{~Pb}$ & ${ }^{207} \mathrm{~Pb} /{ }^{206} \mathrm{~Pb}$ & ${ }^{208} \mathrm{~Pb} /{ }^{206} \mathrm{~Pb}$ \\
\hline $0-20$ & 7.20 & 0.39 & 23.0 & 18.75 & 85.0 & 0.0549 & 0.8555 & 2.0898 \\
\hline $20-40$ & 6.76 & 0.44 & 29.0 & 18.32 & 104.0 & 0.0553 & 0.8598 & 2.1000 \\
\hline $40-60$ & 6.78 & 0.50 & 34.0 & 20.31 & 106.0 & 0.0553 & 0.8607 & 2.0968 \\
\hline $60-80$ & 6.45 & 0.47 & 31.0 & 21.47 & 109.0 & 0.0554 & 0.8609 & 2.0950 \\
\hline $80-100$ & 5.88 & 0.57 & 36.0 & 26.38 & 119.0 & 0.0560 & 0.8714 & 2.1104 \\
\hline $100-120$ & 3.01 & 0.30 & 22.0 & 19.89 & 89.0 & 0.0556 & 0.8654 & 2.1066 \\
\hline $120-140$ & 4.68 & 0.47 & 28.0 & 27.96 & 105.0 & 0.0555 & 0.8622 & 2.0999 \\
\hline $140-160$ & 4.24 & 0.53 & 28.0 & 34.70 & 111.0 & 0.0562 & 0.8724 & 2.1116 \\
\hline $160-180$ & 7.16 & 0.80 & 44.0 & 50.82 & 144.0 & 0.0559 & 0.8693 & 2.1094 \\
\hline Mean & 5.79 & 0.49 & 31.0 & 26.51 & 108.0 & 0.0555 & 0.8641 & 2.1021 \\
\hline S.D & 1.48 & 0.13 & 6.78 & 10.57 & 17.12 & 0.0004 & 0.0057 & 0.0076 \\
\hline Skewness & -0.95 & 1.17 & 0.79 & 1.80 & 0.92 & 0.08 & 0.20 & -0.20 \\
\hline Kurtosis & -0.31 & 2.83 & 0.78 & 3.25 & 1.98 & -0.47 & -1.18 & -1.29 \\
\hline Criterion A [19] & 6 & 1.5 & 40 & 50 & 110 & - & - & - \\
\hline Criterion B & 30 & 5 & 100 & 500 & 500 & - & - & - \\
\hline Criterion C & 50 & 20 & 500 & 1500 & 1500 & 一 & - & 一 \\
\hline
\end{tabular}




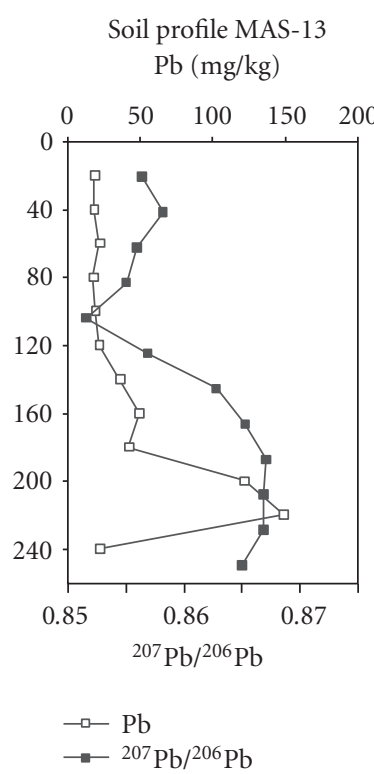

(a)

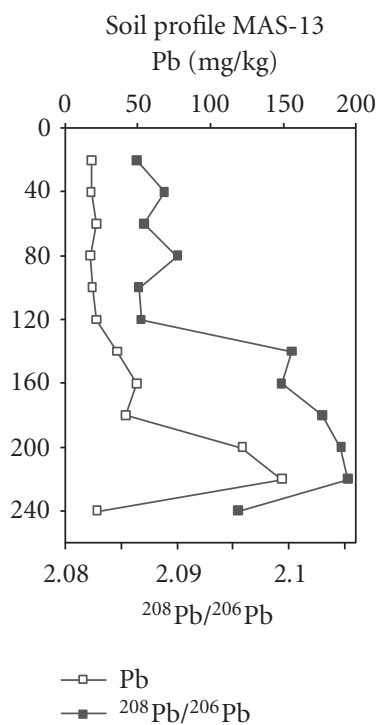

(e)

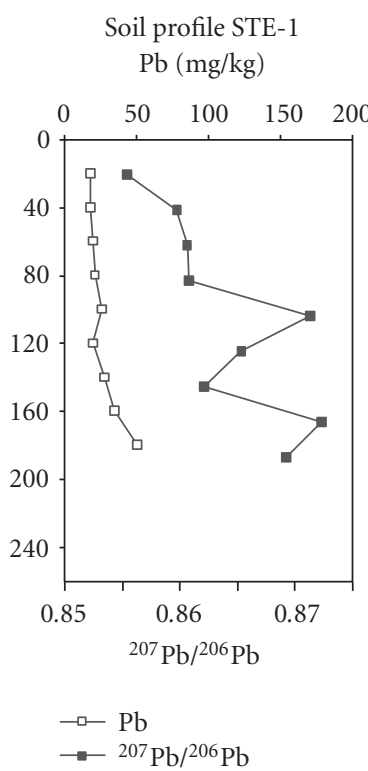

(b)

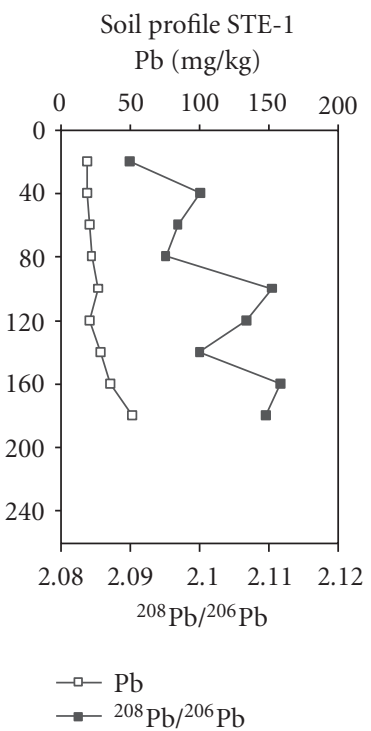

(f)

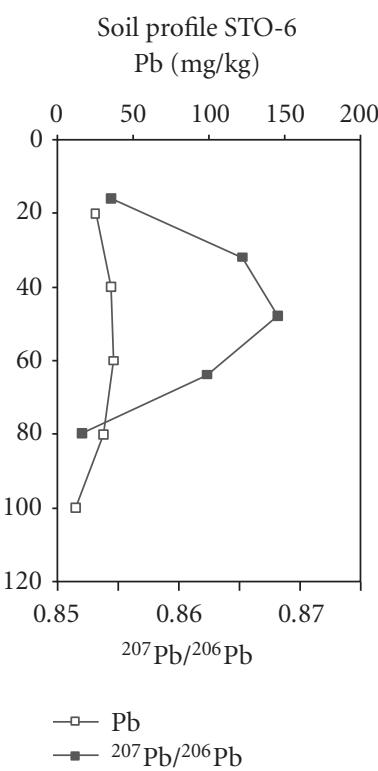

(c)

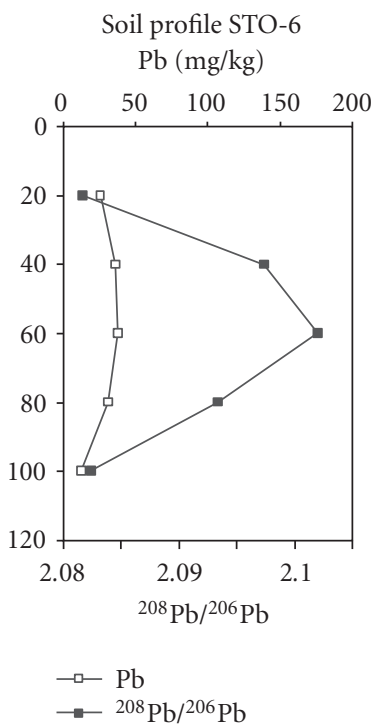

$(\mathrm{g})$

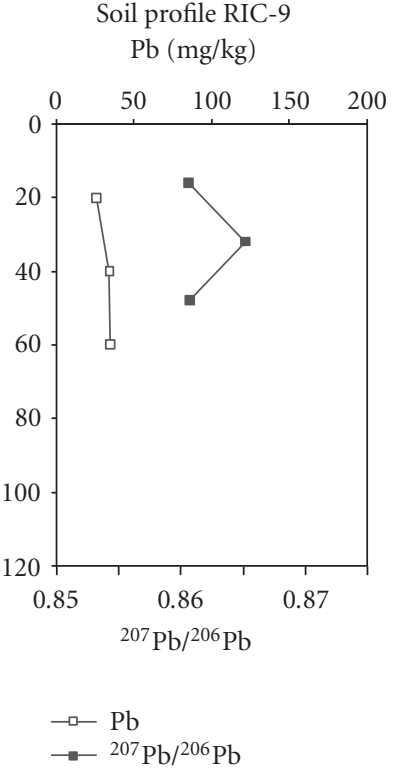

(d)

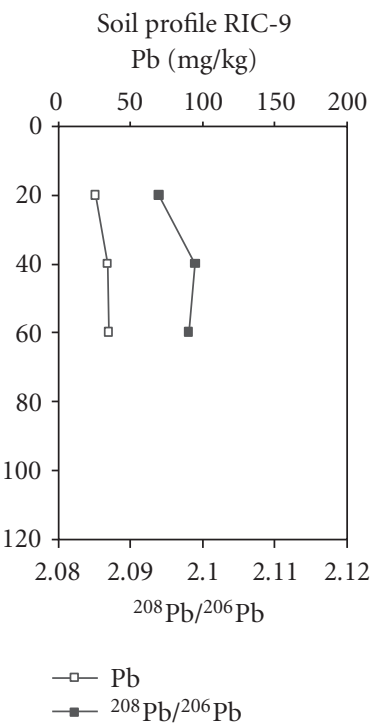

(h)

FIGURE 4: Concentrations of lead and lead isotopic ratios in soil profiles (STE-1, STO-6, RIC-9 and MAS-13). The graph shows several peaks that could be associated with various contamination events recorded in soil profiles.

the ${ }^{208} \mathrm{~Pb} /{ }^{206} \mathrm{~Pb}$ ratios obtained for the STE- 1 and MAS13 soil profiles ranged from 2.089 to 2.111 and 2.086 to 2.105 , respectively. The highest variations were recorded in the STO-6 profile, but there were also significant differences in the MAS-13 and STE- 1 profiles. It is interesting to note that the differences between the isotope ratios are more pronounced at the bottom of the profiles.

\subsection{Trends of Lead versus Isotope Ratios and Contamination} Events. The concentrations of lead in two soil profiles (STE1 and MAS-13) are higher at the bottom of the profiles with peaks at 160, 180 and $220 \mathrm{~cm}$ (Figure 3 ). The concentrations of As at different depths in profiles STE-1 and MAS-13 also exhibit a similar pattern with maximum peaks at 160 , 180 and $220 \mathrm{~cm}$ and another peak for the Cd concentration at $220 \mathrm{~cm}$ for profile MAS-13. For profile STO-6, the two maximum peaks for the As and $\mathrm{Cd}$ concentrations are reached at depths of 80 and $40 \mathrm{~cm}$, and similar depths for the $\mathrm{Pb}$ concentration. By examining only lead in profiles STE-1, STO-6 and MAS-13, it was found that the concentration of this element gradually increases according to the depth. This was also the case for the concentration of As, except for the STO-6 profile. The similarity of soil profile curves suggest at 


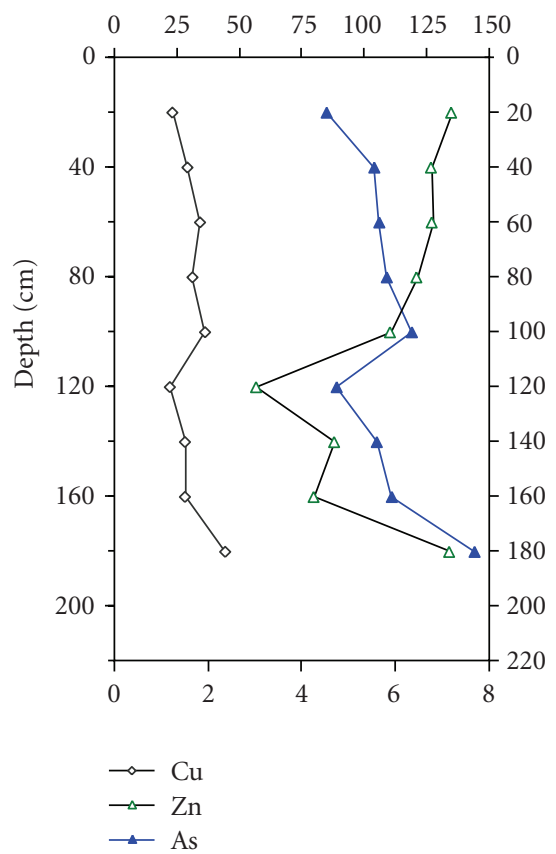

(a)

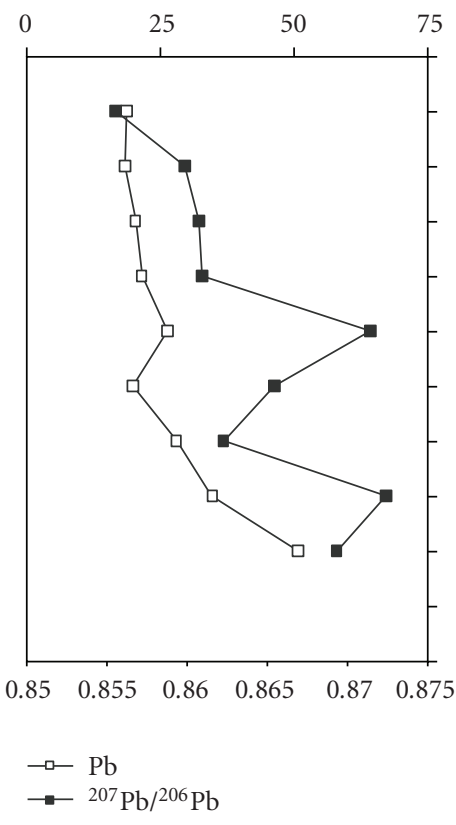

(b)

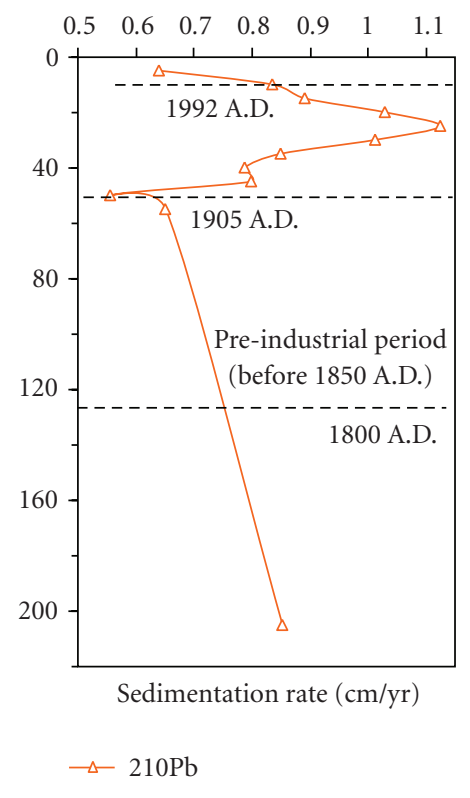

(c)

FIGURE 5: Geochemical and isotopic graphs of STE-1 soil profile, with sedimentation rates (cm/y) obtained by isotopic 210-lead (CRS model).

least two to three major contamination events that might be associated with spills or releases of pollutants into the waters of the Massawippi and Saint-François rivers. Moreover, lead concentration levels are in fact highest in the hydrocarbon layers, that is, $50.82 \mathrm{mg} \mathrm{kg}^{-1}(180 \mathrm{~cm})$ for the STE-1 profile and $149.13 \mathrm{mg} \mathrm{kg}^{-1}(220 \mathrm{~cm})$ for the MAS-13 profile. The peaks recorded on the bottom of the profiles $(160,180$, $220 \mathrm{~cm}$ ) could be explained by oil spills or other petroleumbased products spills that occurred when water levels were at their lowest. It is very unlikely that the lead found at the bottom of the profiles is due to the leaching of this element to this depth. Lead fractions are not very mobile in soils and tend to be concentrated in surface horizons [36,37]. Furthermore, the highest concentrations of lead analyzed in the profiles are associated with the layer of hydrocarbons most often found at the bottom of the profiles, especially in the Massawippi area where lead levels are the highest. Lastly, note that hydrocarbon compounds (e.g., gasoline, motor or fuel oils) are water immiscible and their migration into the groundwater is scant $[38,39]$.

It is nonetheless difficult to confirm the precise origin of the hydrocarbon $\left(\mathrm{C}_{10}-\mathrm{C}_{50}\right)$ contamination observed in the soil profiles. Furthermore, no study on contaminated soils or on the level of chemicals and isotopes in the natural soil in this area has been done. The only study that can be used for comparison comes from the Ministère des Ressources naturelles [40], which provides the concentration of various heavy metals obtained from the soil and sediment samples for sector A4 of the Appalachian geological region where our study area is located. Based on this study, the values obtained for the average concentration of $\mathrm{As}, \mathrm{Cu}, \mathrm{Pb}$ and
$\mathrm{Zn}$ in the soil and sediments (natural background values) are $11.1 \mathrm{mg} \mathrm{kg}^{-1}$ (SD 10.1), $11.5 \mathrm{mg} \mathrm{kg}^{-1}$ (SD 66.5), $15.3 \mathrm{mg}$ $\mathrm{kg}^{-1}$ (SD 17.5) and $67.3 \mathrm{mg} \mathrm{kg}^{-1}$ (SD 82.3), respectively. If these values are compared to those obtained in our profiles, the concentration exceeds the background rates by factors of 1.5 to 10 for the MAS-13 profile (excluding As), and is two to three times higher for the three other profiles (STE1, STO-6, RIC-9), excluding arsenic. Records show relatively high concentrations of copper $\left(44 \mathrm{mg} \mathrm{kg}^{-1}\right)$ and $\mathrm{Pb}$ and $\mathrm{Zn}$ (50.82 and $144 \mathrm{mg} \mathrm{kg}^{-1}$ ) in the STE-1 profile (Table 3) at the base of the profile (80-100 and $160-180 \mathrm{~cm}$ ) that may have originated from the Eustis mine. Part of these elements that may originate from former mining sites might have been carried downstream to the Windsor (STE-1) and Richmond (STO-6) sites. It is equally possible that the metallic content in the atmospheric dust produced by the mine accumulated on the subsurface horizons, though the $\mathrm{Cu}$ values are not overly high (between 29 and $34 \mathrm{mg} \mathrm{kg}^{-1}$ ) at the STE-1 profile, for example (see [33]). The ore extracted from the Eustis site consisted of copper and pyrite (chalcopyrite mineral), and about 39,000 tons of ore (copper mainly) were extracted annually from 1865 to 1939 [41].

Stable isotope ratios $\left({ }^{207} \mathrm{~Pb} /{ }^{206} \mathrm{~Pb}\right.$ and $\left.{ }^{208} \mathrm{~Pb} /{ }^{206} \mathrm{~Pb}\right)$ obtained for lead in the MAS-13 profile indicate a close similarity with the lead concentration profile (Figure 4). The correlation between ${ }^{207} \mathrm{~Pb} /{ }^{206} \mathrm{~Pb}$ and ${ }^{208} \mathrm{~Pb} /{ }^{206} \mathrm{~Pb}$ lead ratios in the same profile is exetremely high $\left(r^{2}=0.96\right.$, $P<.05, n=12)$, and high between lead concentrations and ${ }^{207} \mathrm{~Pb} /{ }^{206} \mathrm{~Pb}$ and ${ }^{208} \mathrm{~Pb} /{ }^{206} \mathrm{~Pb}$ ratios $\left(r^{2}=0.66\right.$ and $\left.r^{2}=0.78\right)$. The various peaks (at $160,200,220 \mathrm{~cm}$ ) in the MAS-13 profile suggest a series of contamination events 
that include at least one that can be related to an oil spill (hydrocarbons layer at $200-220 \mathrm{~cm}$ ). The isotope values at the base of the profile are different from those obtained on the subsurface horizons $(20-40 \mathrm{~cm})$. The values obtained from the soil sample contaminated with hydrocarbons for the STE-1 profile $(180 \mathrm{~cm}$ in depth) indicate isotopic values ranging from $0.869\left({ }^{207} \mathrm{~Pb} /{ }^{206} \mathrm{~Pb}\right)$ to $2.109\left({ }^{208} \mathrm{~Pb} /{ }^{206} \mathrm{~Pb}\right)$, respectively. These represent values significantly different from the ones estimated for the surface profile $(0-20 \mathrm{~cm})$ : $0.855\left({ }^{207} \mathrm{~Pb} /{ }^{206} \mathrm{~Pb}\right)$ and $2.089\left({ }^{208} \mathrm{~Pb} /{ }^{206} \mathrm{~Pb}\right)$. Also, in profile STE-1, concentration levels of lead are reached at a depth of $180 \mathrm{~cm}$, with a value of $50.82 \mathrm{mg} \mathrm{kg}^{-1}$ (Figure 4). By comparing the isotope ratios obtained for the MAS-13 (0.869 for $\left.{ }^{207} \mathrm{~Pb} /{ }^{206} \mathrm{~Pb}\right)$ and STE- 1 profiles $\left(0.855\right.$ for $\left.{ }^{207} \mathrm{~Pb} /{ }^{206} \mathrm{~Pb}\right)$ are slightly different for each profile. This is an indication that the source of pollution may be different, either associated with petroleum product spills (e.g., gasoline, fuel oils) or other pollutant discharge. Considering the position of the peaks $(160,180,200$ and $220 \mathrm{~cm})$ of the lead isotope ratios recorded in the soil profiles sampled from the Massawippi (MAS-13) and Saint-François riverbanks (STE-1), it is possible, however, that at least two separate contamination events took place at different time intervals. For the STO-6 profile, there are slightly higher lead concentration levels at depths of 40 and $60 \mathrm{~cm}$ and where the associated isotope values are $0.865-0.868\left({ }^{207} \mathrm{~Pb} /{ }^{206} \mathrm{~Pb}\right)$ and $2.097-2.102\left({ }^{208} \mathrm{~Pb} /{ }^{206} \mathrm{~Pb}\right)$, respectively, which are values that are relatively different from those observed for the other profiles (MAS-13, STE-1).

In order to estimate the relative period of the deposits found in the alluvial soils of the STE-1 profile, the 210lead method (CRS Model-Constant Rate of Supply) was used to get a chronological series of sediment deposits and to assess the average annual rates of sedimentation for the site. Figure 5 presents the data that compare the different concentrations of metallic trace elements (e.g., As, $\mathrm{Cu}, \mathrm{Zn}$ ) for the STE-1 profile (Figure 5(a)), the concentration levels of the lead and isotope ratios (Figure 5(b)), in addition to the rates of sedimentation and calendar dates collected by the CRS Model (Figure 5(c)). The strongest concentrations of trace elements are recorded at the base of the profile (160$180 \mathrm{~cm}$ ), precisely in the layer with the highest hydrocarbon contamination. The evidence shows that the hydrocarbon layer has permeated the fluvial deposits dated before or during 1700-1800 (in pre-industrial times) (Figure 5(c)). Remember that mining operations began in the region in the 1850's with the opening of copper mines in the Ascot Township, including the Ascot (1851-1864), Belvedere (1864-1865) and Eustis-Capelton mines (1863-1865) [41]. It was only later in the 1900s and 1910s that extensive industrial activities such as wood processing, pulp and paper, heavy industries, chemical procedures took place although as early as 1850 various industries came to the region (textile and pulp and paper) [42].

Since contaminants were found at the base of the profiles, in particular in the alluvium which was deposited prior to the pre-industrial era, it can be shown that the rivers had reached very low levels that correspond perhaps to a prolonged low flow period (a very dry summer-fall season, for example). Finally, a second contamination peak is noted
(As, $\mathrm{Cu}, \mathrm{Pb}, \mathrm{Zn}$ ) at a depth of $100 \mathrm{~cm}$ in the profile that could be attributed to another contamination event associated with the discharge of pollutants in the river that may have infiltrated more recent deposits (between 1800 and 1850). In this respect, it is interesting to note in Figure 5(c) how the sedimentation rates have sharply increased during recent years, in particular in the 1970's and 1980's. The mean annual sedimentation rate is evaluated at $0.79 \mathrm{~cm} / \mathrm{y}(1973-1992)$. This increase in sedimentation rates actually corresponds to an increase in flood events during the same period $[17,43]$.

\section{Conclusions}

Focusing on the contamination levels of the alluvial soils of the Saint-François and Massawippi rivers (in southern Québec), the results of this study showed that pollutants (hydrocarbons and trace elements $\mathrm{As}, \mathrm{Cd}, \mathrm{Pb}$ and $\mathrm{Zn}$ ) carried by the rivers can travel very long distances (over $100 \mathrm{~km}$ ) and that the infiltration of these pollutants into the riverbanks is conditioned by factors such as hydrodynamic conditions (low levels of water, floods, etc.). In addition, the fluvial transport of pollutants turned out to be a relatively complex phenomenon because of the effect of recurring floods on the stirring up of fine sediments. By comparing the values obtained between soil profiles, the maximum and minimum values detected for arsenic, cadmium and lead vary from 3.01 to $37.88 \mathrm{mg} \mathrm{kg}^{-1}$ (As), 0.11 to $0.81 \mathrm{mg} \mathrm{kg}^{-1}$ (Cd), and 12.32 to $149.13 \mathrm{mg} \mathrm{kg}^{-1}(\mathrm{~Pb})$, respectively, while the ${ }^{207} \mathrm{~Pb} /{ }^{206} \mathrm{~Pb}$ isotopic ratio values vary from 0.8545 to 0.8724 for all the profiles. The highest values of the trace elements (As, $\mathrm{Pb}$ and $\mathrm{Zn}$ ) were detected in the hydrocarbon layer $\left(\mathrm{C}_{10}-\mathrm{C}_{50}\right)$, most often located at the bottom of the profiles $(160,200$ and $220 \mathrm{~cm}$ in depth). The various peaks recorded in the soils and their position in the profiles suggest that various contaminants were transported by the river on several occasions and infiltrated the soil matrix or were deposited on floodplains during successive floods. Atmospheric particles which enter the river or deposited on riverbanks must also be considered as another source of pollution recorded in alluvial soils. In this study, it was found that alluvial soils are the efficient "environmental archives" that allow past contamination events to be traced and, as a result, can serve as an indication of the way contaminants can persist in the environment for a long period of time.

Attention is drawn to the importance of combining analytical methods of contaminant concentrations (including lead), which include isotope ratios of lead methods. Using only the concentration of trace metals in alluvial soils does not seem sufficient for detecting different levels of contamination in riverbank profiles. Dating methods (e.g., lead-210) used in combination with contaminant analysis can also turn out to be an additional analytical tool for interpreting data. Finally, the study shows that sediments found on the surface $(0-20 \mathrm{~cm})$ of alluvial soils are less contaminated than at deeper layers, pointing to evidence that water quality has in fact improved over time, owing to better management of pollutant discharge by municipal and government authorities over the last 10 to 20 years. 
The next phases of this study will increase the number of soil samples in areas outside of floodplain zones (e.g., forested, upland, with little or no disruption by human activities) to discriminate between pollutant inputs associated with fluvial transport or atmospheric deposition.

Also, the use of comparative methods between $\mathrm{Pb}-\mathrm{Sc}$ and $\mathrm{Pb}-\mathrm{Zr}$ ( $\mathrm{Sc}$ and $\mathrm{Zr}$ are conservative metals [44] with no significant anthropogenic source) will be evaluated. These will permit to better discriminate between natural background $\mathrm{Pb}$ and anthropogenic $\mathrm{Pb}$.

\section{Acknowledgments}

The authors would like to thank Natural Sciences and Engineering Research Council of Canada (NSERC) for their financial support. They would like to acknowledge sincerely the reviewers for their constructive comments. They would like also to acknowledge the Geological Commission of Canada (GCC-Québec) and INRS-ETE laboratory's support for the soil analyses and also the GEOTOP-UQAM-McGill laboratory.

\section{References}

[1] M. Komárek, V. Ettler, V. Chrastny, and M. Mihaljevic, "Lead isotopes in environmental sciences: a review," Environment International, vol. 34, no. 4, pp. 562-577, 2008.

[2] Y. Erel, A. Veron, and L. Halicz, "Tracing the transport of anthropogenic lead in the atmosphere and in soils using isotopic ratios," Geochimica et Cosmochimica Acta, vol. 61, no. 21, pp. 4495-4505, 1997.

[3] W. Shotyk, D. Weiss, P. G. Appleby, et al., "History of atmospheric lead deposition since $12,370{ }^{14} \mathrm{C}$ Yr BP from a peat bog, jura mountains, Switzerland," Science, vol. 281, no. 5383, pp. 1635-1640, 1998.

[4] C. Zaccone, C. Cocozza, A. K. Cheburkin, W. Shotyk, and T. M. Miano, "Highly organic soils as "witnesses" of anthropogenic $\mathrm{Pb}, \mathrm{Cu}, \mathrm{Zn}$, and ${ }^{137} \mathrm{Cs}$ inputs during centuries," Water, Air, and Soil Pollution, vol. 186, no. 1-4, pp. 263-271, 2007.

[5] C. Zaccone, A. Gallipoli, C. Cocozza, M. Trevisan, and T. M. Miano, "Distribution patterns of selected PAHs in bulk peat and corresponding humic acids from a Swiss ombrotrophic bog profile," Plant and Soil, vol. 315, no. 1-2, pp. 35-45, 2009.

[6] A. Bollhöfer and K. J. R. Rosman, "Isotopic source signatures for atmospheric lead: the Northern Hemisphere," Geochimica et Cosmochimica Acta, vol. 65, no. 11, pp. 1727-1740, 2001.

[7] J. M. Pacyna, M. T. Scholtz, and Y. F. Li, "Global budget of trace metal sources," Environmental Reviews, vol. 3, no. 2, pp. 145-159, 1995.

[8] W. T. Sturges and L. A. Barrie, "Lead 206/207 isotope ratios in the atmosphere of North America as tracers of US and Canadian emissions," Nature, vol. 329, no. 6135, pp. 144-146, 1987.

[9] V. Ettler, M. Mihaljevic, O. Sebek, M. Molek, T. Grygar, and J. Zeman, "Geochemical and $\mathrm{Pb}$ isotopic evidence for sources and dispersal of metal contamination in stream sediments from the mining and smelting district of Príbram, Czech Republic," Environmental Pollution, vol. 142, no. 3, pp. 409417, 2006.
[10] J. Klaminder, R. Bindler, H. Laudon, K. Bishop, O. Emteryd, and I. Renberg, "Flux rates of atmospheric lead pollution within soils of a small catchment in Northern Sweden and their implications for future stream water quality," Environmental Science and Technology, vol. 40, no. 15, pp. 4639-4645, 2006.

[11] J. R. Miller, P. J. Lechler, G. Mackin, D. Germanoski, and L. F. Villarroel, "Evaluation of particle dispersal from mining and milling operations using lead isotopic fingerprinting techniques, Rio Pilcomayo Basin, Bolivia," Science of the Total Environment, vol. 384, no. 1-3, pp. 355-373, 2007.

[12] J. M. Bacon, I. J. Hewitt, and P. Cooper, "Origin of lead associated with different reactive phases in Scottish upland soils: an assessment made using sequential extraction and isotope analysis," Journal of Environmental Monitoring, vol. 6, no. 9, pp. 766-773, 2004.

[13] R. Swennen, I. Van Kerr, and W. De Vos, "Heavy metal contamination in overbank sediments of the Geul river (East Belgium). Its relation to former $\mathrm{Pb}-\mathrm{Zn}$ mining activities," Environmental Geology, vol. 24, no. 1, pp. 12-21, 1994.

[14] M. Bäckström, H. Bohlin, S. Karlsson, and N. G. Holm, "Element ( $\mathrm{Ag}, \mathrm{Cd}, \mathrm{Cu}, \mathrm{Pb}, \mathrm{Sb}, \mathrm{Tl}$ and $\mathrm{Zn}$ ), element ratio and lead isotope profiles in a sediment affected by a mining operation episode during the late 19th century," Water, Air, and Soil Pollution, vol. 177, no. 1-4, pp. 285-311, 2006.

[15] A. T. de Matos, M. P. F. Fontes, L. M. da Costa, and M. A. Martinez, "Mobility of heavy metals as related to soil chemical and mineralogical characteristics of Brazilian soils," Environmental Pollution, vol. 111, no. 3, pp. 429-435, 2001.

[16] U. K. Haack, H. Heinrichs, F. H. Gutsche, and K. Plessow, "The isotopic composition of anthropogenic $\mathrm{Pb}$ in soil profiles of Northern Germany: evidence for pollutant $\mathrm{Pb}$ from a continent-wide mixing system," Water, Air, and Soil Pollution, vol. 150, no. 1-4, pp. 113-134, 2003.

[17] D. Saint-Laurent, J. St-Laurent, L. Lavoie, and B. Ghaleb, "Use geopedological methods for the evaluation of sedimentation rates on river floodplains, southern Québec, Canada," Catena, vol. 73, no. 3, pp. 321-337, 2008.

[18] R. A. Kehoe, "Contaminated and natural lead environments of man," Archives of Environmental Health, vol. 11, no. 5, pp. 736-739, 1965.

[19] Canadian Environmental Protection Act (CEPA), "Lead-Free gasoline regulations," C.R.C., c. 408, Environment Canada, SOR/90-247, Ottawa, Canada, 1990.

[20] L. Lavoie, D. Saint-Laurent, and J. St-Laurent, "Pedological and sedimentological analyses of alluvial soils and paleosols on floodplain terraces," Canadian Journal of Soil Science, vol. 86, no. 5, pp. 813-826, 2006.

[21] Ministère du Développement durable, de l'Environnement et des Parcs (MDDEP), "Répertoire des dépôts de sols et résidus industriels," Québec, Canada, 2002, http://www.mddep.gouv .qc.ca/sol/residus_ind/resultats.asp.

[22] D. Berryman, J. St-Onge, A. Gendron, and C. Brochu, "L'impact d'anciens parcs à résidus miniers sur la qualité de l'eau et les communautés benthiques de la rivière Massawippi et des ruisseaux Eustis et Capel," Ministére de l'Environnement, Québec, Canada, 2003.

[23] Canada Soil Information System (CanSIS), Manual for Describing Soil in the Field, Expert Committee on Soil Survey, Research Branch, Agriculture Canada, Ottawa, Canada, 1982.

[24] Soil Classification Working Group (SCWG), The Canadian System of Soil Classification, National Research Council, Ministery of Agriculture and Agri-Food Canada, Ottawa, Canada, 3rd edition, 1998. 
[25] M. R. Carter, "Soil sampling and methods of analysis," in Canadian Society of Soil Science, Lewis, Boca Raton, Fla, USA, 1993.

[26] J. C. Yeomans and J. M. Bremner, "A rapid and precise method for routine determination of organic carbon in soil," Communications in Soil Science \& Plant Analysis, vol. 19, no. 13, pp. 1467-1476, 1988.

[27] Ministére du Développement durable, de l'Environnement et des Parcs (MDDEP), "Politique de protection des sols et de réhabilitation des terrains contaminés, annexe 2: les critères génériques pour les sols et pour les eaux souterraines," Québec, Canada, 2002.

[28] Centre d'expertise en analyse environnementale du Québec (CEAEQ), "Méthode d'analyse-détermination des métaux assimilables: méthode par spectrométrie de masse à source ionisante au plasma d'argon,” MA. 200, Mét. 1.1, Révision, 2006-12-05 (3), Québec, Canada, 2006.

[29] P. G. Appleby and F. Oldfield, "The calculation of lead-210 dates assuming a constant rate of supply of unsupported $210 \mathrm{~Pb}$ to the sediment," Catena, vol. 5, no. 1, pp. 1-8, 1978.

[30] J. O. Nriagu, "A history of global metal pollution," Science, vol. 272, no. 5259, pp. 223-224, 1996.

[31] B. E. Davies, "Heavy metal contaminated soils in an old industrial area of Wales, Great Britain: source identification through statistical data interpretation," Water, Air, and Soil Pollution, vol. 94, no. 1-2, pp. 85-98, 1997.

[32] J. M. Bubb and J. N. Lester, "Factors controlling the accumulation of metals within fluvial systems," Environmental Monitoring and Assessment, vol. 41, no. 1, pp. 87-105, 1996.

[33] D. Saint-Laurent, M. Hähni, and J. St-Laurent, "Spatial distribution and characterization of contaminated soils in riverbanks of Saint-François and Massawippi Rivers (Southern Québec, Canada)," Water Quality Research Journal of Canada, vol. 43, no. 2-3, pp. 99-109, 2008.

[34] Centre d'Expertise Hydrique du Québec (CEHQ), "Suivi hydrologique de différentes stations hydrométriques," Québec, Canada, 2009, http://www.cehq.gouv.qc.ca/suivihydro/index .asp.

[35] K. Hilscherova, L. Dusek, V. Kubik, et al., "Redistribution of organic pollutants in river sediments and alluvial soils related to major floods," Journal of Soils and Sediments, vol. 7, no. 3, pp. 167-177, 2007.

[36] J. M. Kaste, A. J. Friedland, and S. Sturup, "Using stable and radioactive isotopes to trace atmospherically deposited $\mathrm{Pb}$ in Montane forest soils," Environmental Science and Technology, vol. 37, no. 16, pp. 3560-3567, 2003.

[37] N. Walraven, B. J. H. Van Os, G. T. H. Klaver, J. H. Baker, and S. P. Vriend, "Trace element concentrations and stable lead isotopes in soils as tracers of lead pollution in Graft-De Rijp, the Netherlands," Journal of Geochemical Exploration, vol. 59, no. 1, pp. 47-58, 1997.

[38] Bureau de Recherches Géologiques et Minières (BRGM), Guide sur le Comportement des Polluants dans le Sol et les Nappes, Ministère de l'aménagement du territoire et de l'environnement, Paris, France, 2001.

[39] A. W. Rose, H. E. Hawkes, and J. S. Webb, Geochemistry in Mineral Exploration, Academic Press, London, UK, 2nd edition, 1979.

[40] J. Choinière and M. Beaumier, "Bruits de fond géochimiques pour différents environnements géologiques au Québec," Ministère des Ressources Naturelles, Québec, Canada, no. 60, 1997.
[41] Ministère des Ressources Naturelles et Faune (MRNF), "Estrie-activités minières," Québec, Canada, 2007, http:// www.mrnf.gouv.qc.ca/Estrie/mines/mines-activite.jsp.

[42] P. Southam, "Continuity and change in Eastern Townships manufacturing industry," Journal of Eastern Townships Studies, vol. 18, pp. 5-18, 2001.

[43] D. Saint- Laurent, M. Mesfioui, and G. Evin, "Hydroclimatic variability and relation with flood events (Southern Québec, Canada)," Water Resources, vol. 36, no. 1, pp. 43-56, 2009.

[44] W. Shotyk, P. Blaser, A. Grünig, and A. K. Cheburkin, "A new approach for quantifying cumulative, anthropogenic, atmospheric lead deposition using peat cores from bogs: $\mathrm{Pb}$ in eight Swiss peat bog profiles," The Science of the Total Environment, vol. 249, no. 1-3, pp. 281-295, 2000. 

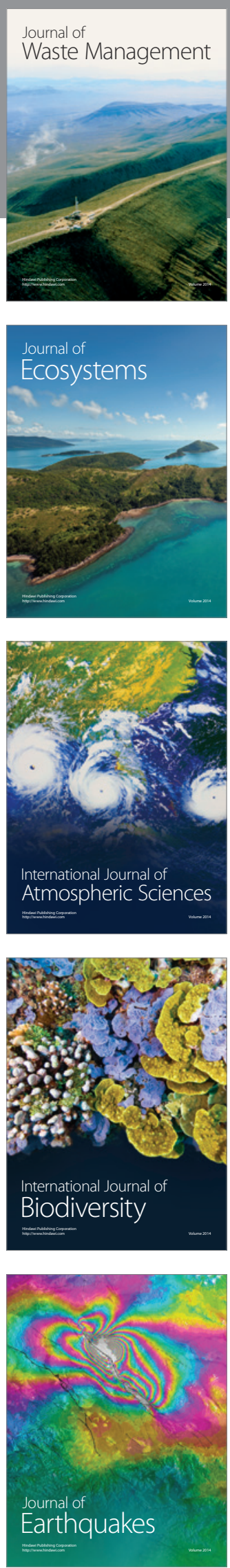
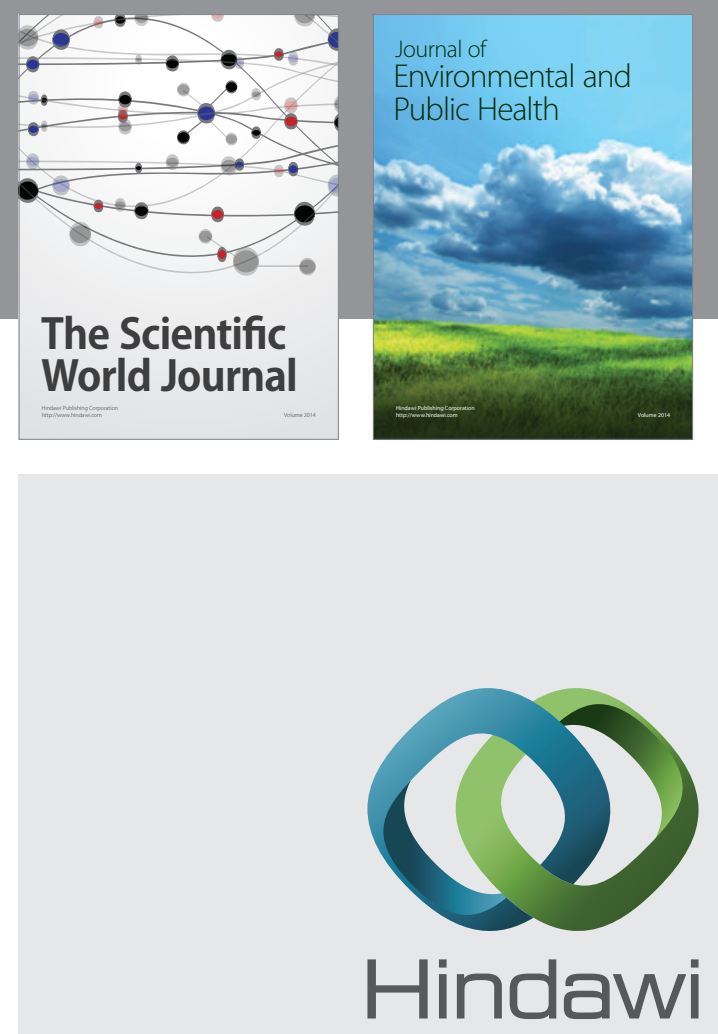

Submit your manuscripts at

http://www.hindawi.com
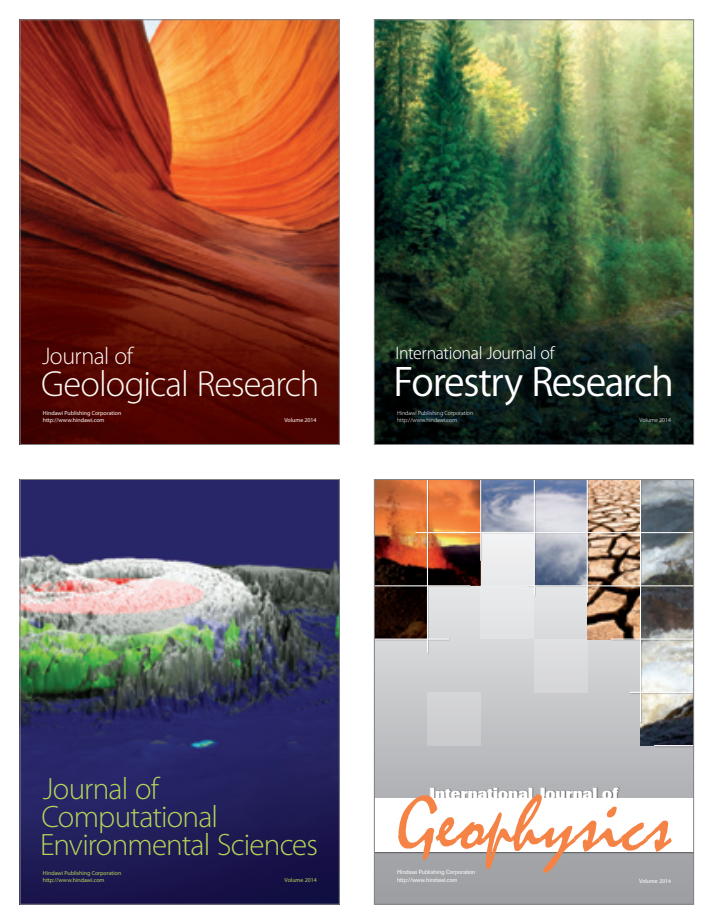
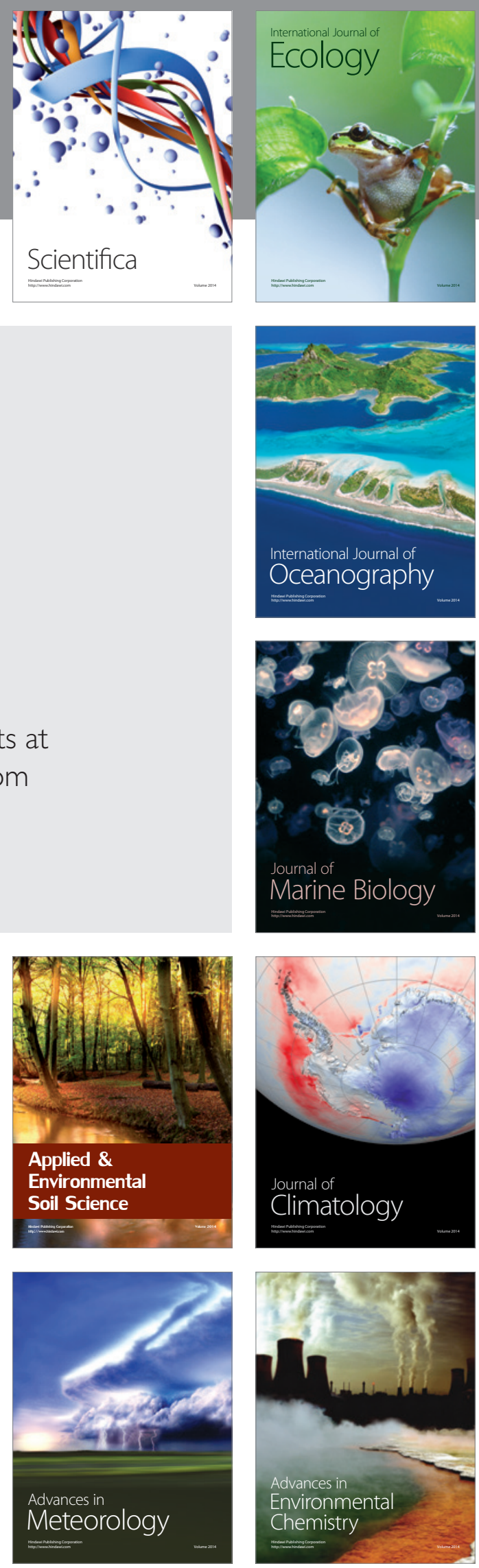